109

挼宫りパーシティ・ウォータータワープラザ

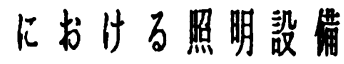

$$
\text { その } 2 \text {-中庭ボィト周边の照明設䚚 }
$$

$$
\begin{aligned}
& \text { 斉藤淦田信行片山就司 } \\
& \text { （株式会社林組）（松下電工株式会社） }
\end{aligned}
$$

1.はじにに本建物は、その1で示し たように、地上41階の超高層集合住宅でお るが、図1のように建物中央に吹抜けの中 庭ボイト（18.4 m $\times 15.1 \mathrm{~m} ）$ を有し、この周 边に廊下を眍している。最近他の高層集合 住宅においてす中庭ボイドを設けたるのが 多く見受けられるが、その主な理由は、

(1) ボイトに面して廊下を配することによ りこの部分が建筑面積に算入されない

(2) ボイド方式にすることにより、建策平 面的に正方形に近い形になり、周辺の嫄 境に及ほす影踷（日照、電波障害など） が少なくなる

などがあげられる。

このように中庭ボイド方式は建策上の利 点を有するが、採光は一般的に建物頂部の みからのものが多く、このためボイト下部 は昼光の入射量が少なく、昼間時でる非常 に薄暗く、良好な光㻴境が形成され嚾い。

このため本建物の照明計画 - 設計にあた つては、この点に十分留意し、種々の検討、 実験等を行ったのでその概要を報告する。

\section{2. ボイト空間の望ましい光環境の条件}

照明設計にあたっては、照明によって形 成されるへき諸条件（基準）が明確になっ ている必要がある。

このため、中庭ボイドを有する高層集合 住宅 3 事例について、輝度分布、印象評価 などの調査を行ったここれらの調查を元に して抽出されたボイド空間の望ましい光㻴 境条件は以下のようなるのであった。い

（1）ボィト内の鉛直面輝度（壁） $40 . \mathrm{cd} / \mathrm{m}^{2}$ 以上

（2）不均一な光の存在

（3）ボイト下部、中間階などからの昼光の 入 射

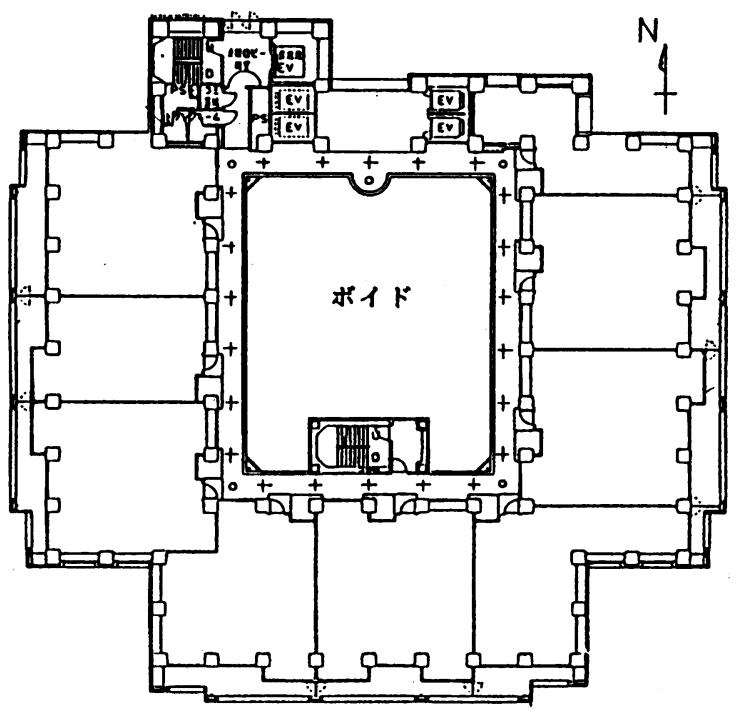

図 1 建筑平面図

（4）ボイドに面する壁等の仕上色暖色系 3. 照明計画の基本コンセプ上 2 . で 示した条件を考虑し、ボイド内の照明設備 は以下のようなコンセプトをむとにして計 画した。

（1）通切な䍩直面唓度を提供できる廊下用 照明器具による対応を主とする

（2）ボイト内に大きな壁面積を有する特別 避難段があるため、この部分への投光 照明を考虑する。

（3）エネルギ一の有効利用を計るため、照 明設備は昼光利用制御、夕イムスヶジュ ール制御を行う。

（4）建物北面加らの採光を考虑する。

4.コンピュータグラフィックスによる事 前評価各照明設傮の最終仕様を決定す るため、廊下用照明、特別避嚾階の壁面 照明とる、事前にコンピュータグラフィッ クスによってコンピュータシミュレーショ ンを行った。

廊下用照明器具については、一般の埋込

Artifical lighting installation in Sakuranomiya River City tater Tover Plaza Part 2-0utline of artifical lighting for voidspace. Mitsurusaito et al. 
下面開放形と複合ハラボリック形状のてル ミ蒸着鏡面反射板を有するバットウイング 匢光の埋込下面開放形との 2 種頻について、 廊下中心配置方式とボイド例へ $100 \mathrm{~mm}$ 偏心 配置方式の 2 方式を比较検討した。尚、光 䃇はいずれる $40 \mathrm{~W}$ 蛍光ランプ 1 奵とした。

また特別避韻階段の壁面照明については、

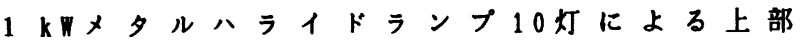
からの投光照明方式と下部からの投光照明 方式の 2 方式とについて検討した。

その結果、廊下用照明はハットゥイング 配光の器具による偏心眍置方式か、特別避 競階段の壁面照明は上部から下部への投光 照明方式が望ましいことがわかった。

5. 現場実験による照明設備の最終仕様の 決定照明設俑の最終仕様を決定するた め、現場において簡易な実娩を行った。実 験は11名の被験者によるてンケート用紙を 使った 5 段階の印象評価方式で行ったが、

照明器具はグレア、意匠上の問題などから コンピュータグライックスで検討したる の以外に、廊下用照明器具は下面に梨地ル 一バをつけたのを、特別避難階段の壁面 照明器具は400Wのると、さらに前面にル 一バをつけたるのを追加した。図2、図 3 は各種実験のうち、特別避難階段の壁面照 明における $1 \mathrm{k}$ 㴗評価と 400 との評価の差 を示す。

このようなステップを释て照明設備の最 終的な仕様が以下のように決定された。

（1）廊下用照明器具 40 1 奵形下面梨 地ルーハ付（図4 参照、2 2 台／階）

（2）特別避嚾階段壁面照明用器具400 メタルハライドンプ投光器、ルーバ 付（設置階 $14 、 21 、 28 、 35 、 41$ 階） 6. 照明設備の制御これらのボイト周 刃の照明設销は、省エネルギ一、エネルギ 一コストの低減化を計るため、以下のよう な制御が考虑された。

（1）廊下用照明多ムスケジュールと 昼光の入射量に応した段調光（100/50 \%) 制御と夜間の間引き点奵制御

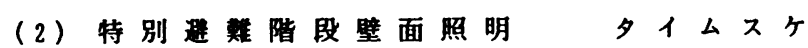
$シ ゙ ュ ー ル と$ 昼光の入射深さによる点隇 制 侥

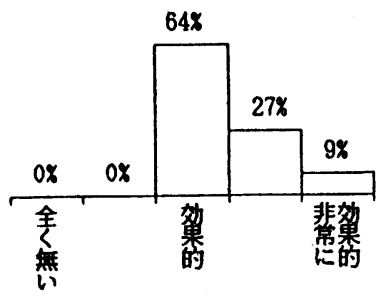

(a) 末・快空間の明 るさ感向上効果

図 $21 \mathrm{k}$ 投光器による評価結果

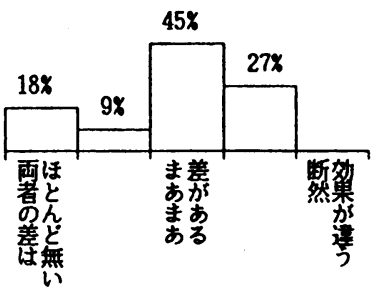

(a) $\star^{*}$ イト空間の明 るさ感向上効果

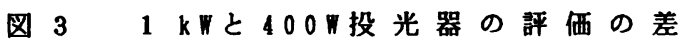

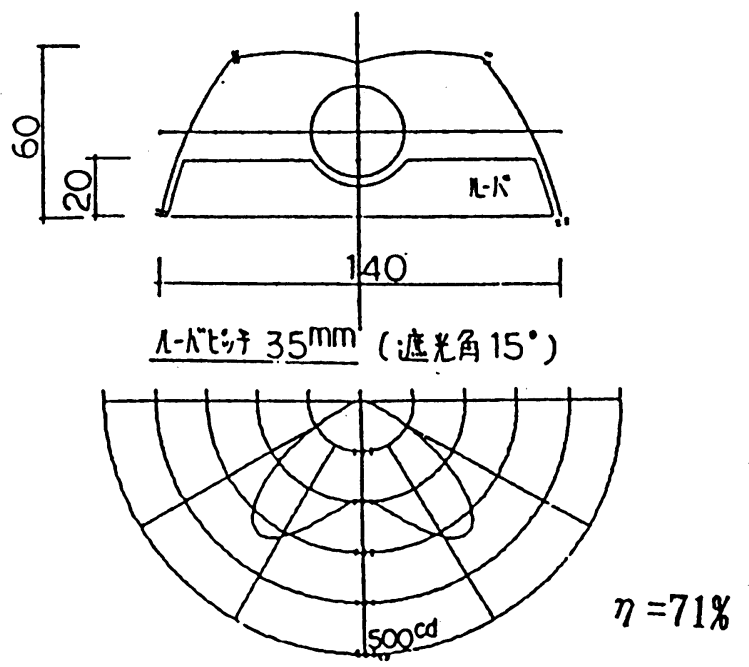

図 4 響下用照明器具（梨地ルーバ付） の断面図と配光特性

7.おわりに高首集合住宅の中庭ボイ ぞ空間は特異な閉敛空間であり、㻴境心理 的にあ大きな課題を抱えた空間である。

今回はこの空間の光㻴境の改善を試子た か、これ以外に自然とのつながりの欠如 感の㭪充策の研究等、検討されなけれはな らない課題が多く、多方面からのさらなる 研究が望まれる。

(参考文献)

1) 斎藤・乾・中村：日本建策学会大会学術 講演梗概集、1989年10月

2)紊藤・浅田・片山：日本建策学会大会学

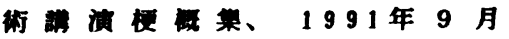

